Division of Geological \& Geophysical Surveys

RAW-DATA FILE 2013-5

\title{
GEOCHEMICAL MAJOR-OXIDE, MINOR-OXIDE, TRACE-ELEMENT, AND RARE-EARTH-ELEMENT DATA FROM ROCKS AND STREAM SEDIMENTS COLLECTED IN 2012 IN THE RAY MOUNTAINS AREA, BEAVER, BETTLES, LIVENGOOD, AND TANANA QUADRANGLES, ALASKA
}

by

Erik N. Bachmann, Michael J. Blessington, Larry K. Freeman, Rainer J. Newberry, Amy L. Tuzzolino, Thomas Colby Wright, and William Wylie

September 2013

(Revised March 2019)

THIS REPORT HAS NOT BEEN REVIEWED FOR

TECHNICAL CONTENT OR FOR CONFORMITY TO THE EDITORIAL STANDARDS OF DGGS

Released by:

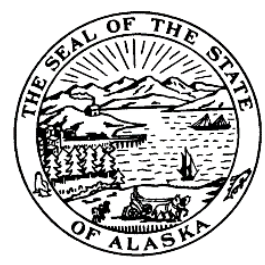

STATE OF ALASKA

DEPARTMENT OF NATURAL RESOURCES

Division of Geological \& Geophysical Surveys

3354 College Road | Fairbanks, Alaska 99709-3707

Phone 907-451-5020

Fax 907-451-5050

dggspubs@alaska.gov

http://dggs.alaska.gov 


\section{GEOCHEMICAL MAJOR-OXIDE, MINOR-OXIDE, TRACE-ELEMENT, AND RARE-EARTH-ELEMENT DATA FROM ROCKS AND STREAM SEDIMENTS COLLECTED IN 2012 IN THE RAY MOUNTAINS AREA, BEAVER, BETTLES, LIVENGOOD, AND TANANA QUADRANGLES, ALASKA}

by

Erik N. Bachmann ${ }^{1}$, Michael J. Blessington ${ }^{1}$, Larry K. Freeman ${ }^{2}$, Rainer J. Newberry ${ }^{3}$, Amy L. Tuzzolino ${ }^{3}$, Thomas Colby Wright ${ }^{1}$, and William Wylie ${ }^{1}$

\section{INTRODUCTION}

Anomalous concentrations of base metals, tin, tungsten, chromium, rare-earth elements (REEs), and uranium were discovered in the Ray Mountains and Kanuti-Hodzana uplands regions of Interior Alaska in the 1970s as part of the National Uranium Resource Evaluation (NURE) Hydrogeochemical and Stream Sediment Reconnaissance (HSSR) program; these historic datasets are currently archived in the National Geochemical Database (Smith, 2006). Subsequent resource assessments by the U.S. Bureau of Mines located and described bedrock and alluvial tin occurrences (Barker and Foley, 1986), bedrock chromite occurrences (Foley and McDermott, 1983), and alluvial rare-earth-element occurrences (Barker, 1992). Mineral-resources personnel from the Alaska Division of Geological \& Geophysical Surveys (DGGS) carried out a helicopter-supported geological and geochemical resource assessment project in the Beaver, Bettles, Livengood, and Tanana quadrangles June 23-August 5, 2012. The objectives of DGGS's resource assessment are to improve the trace-element geochemical coverage of selected watersheds; to obtain modern, quantitative geochemical analyses; to understand the petrogenesis of the granites, and to better document established mineral occurrences. Stream-sediment, pan-concentrate, and rock sampling were conducted as part of the State's Rare-Earth Elements and Strategic Minerals Assessment project, which is designed to evaluate Alaska's potential for these resources. Highlights of this sampling project include documenting patterns of variable REE enrichment in the granites and identifying bedrock samples of greisen and oxidized breccias with enriched REE, and stream sediments with enriched REEs that have a pattern of variation that mimics that of the granites.

The text and analytical data tables associated with this report are being released in digital format like PDF and CSV files, and are available from the DGGS website (doi:10.14509/25386). This updated version of the publication was released in March 2019 with the addition of analyses for tin, niobium, and thorium for 11 pan-concentrate samples (see below) that had over-limit values in the original analyses. Note that the pan-concentrate data still contain several values for chromium and one value for zirconium that are over limits; these over-limit values are not relevant to the evaluation of the tin- and REE- alluvial resources of the region. In addition, there were minor editorial changes to the description of sample collection methods to clarify the methodology.

${ }_{1}^{1}$ Alaska Division of Geological \& Geophysical Surveys, 3354 College Rd., Fairbanks, AK 99709-3707

${ }^{2}$ Alaska Division of Geological \& Geophysical Surveys, 3354 College Rd., Fairbanks, AK 99709-3707; lawrence.freeman@alaska.gov

${ }_{3}^{3}$ Department of Geology \& Geophysics, University of Alaska Fairbanks, P.O. Box 755780, Fairbanks, AK $99775-5780$ 


\section{DOCUMENTATION OF METHODS}

\section{SAMPLE COLLECTION}

Rock samples were collected for two different purposes. Samples of visibly mineralized rock, or rocks exhibiting features associated with mineralization, were preferentially collected and analyzed for geochemical trace elements. Most samples are "grab" samples, which were randomly collected at a location; however, a few samples are "select" samples, which were deliberately collected from a specific feature. These instances are noted in the sample's description. Igneous and meta-igneous rocks showing little alteration or weathering were collected for major-oxide, minor-oxide, and trace-element analyses to determine bulk rock composition of igneous and meta-igneous lithologies, or to identify the tectonic setting of a sample's protolith from petrogenetically important trace elements. Many fine-grained igneous and meta-igneous rocks were collected for "slab" X-ray fluorescence (slab XRF) petrographic analysis, which is a more cost-effective method of determining bulk rock composition for rocks that are fine-grained and have a uniform composition.

Stream-sediment sample locations were selected prior to fieldwork to fulfill two different needs: (1) to fill data gaps between previously collected samples with known anomalous values for REE and related elements; and (2) to fill gaps between previously collected samples. Priority was given to samples closer in proximity to the Dalton Highway-Trans-Alaska Pipeline System corridor and to samples in drainage basins in or near the mapped extent of granitic plutons.

In the field, specific sample locations were selected by visual inspection from the helicopter and were based on the availability of sample material and a suitable landing zone. Specific sites along streams and/or rivers at the sample location were then selected, in order of preference from highest to lowest, as follows: gravel/cobble-armored riffles and point bars, log/boulder/plunge-pool eddies, point bars, overbank flood deposits, and moss mats. Stream-sediment samples were collected with a shovel. Cobbles and larger pebbles were manually removed; there was no field screening. The remaining material was placed into a permeable cloth sample bag and air dried at camp. To ensure a sufficient volume of fine sediment, 7-inch-wide by 12inch-long synthetic-cloth sample bags were filled to capacity.

Pan-concentrate samples were collected with a shovel and screened using a "Garrett's Combination Sifter" with a 0.483 -inch, square-hole mesh. The resulting undersized material was collected in a 14-inch-diameter "Garrett's Gold Trap" gold pan. Sediments were screened until the gold pan was level full with -0.483 inch material. Using alternating shaking and washing motions, the sediment was reduced to visible heavy minerals or a volume of approximately $30 \mathrm{ml}$. This concentrate was then washed into Nasco Whirl-Pak plastic sample bags and placed into another cloth bag.

Location data were collected using Trimble TSC3 WAAS-enabled GPS devices running ArcPad 10. Data were downloaded directly from the ArcPad AXF file into a field geodatabase set up in ArcMap. WAASenabled GPS devices have a reported error of about 1 meter. Sample points that were placed in the database without GPS have an estimated error ranging from 20 to 170 meters. Latitude and longitude were calculated from the GPS's UTM zone values in ArcMap using the 'calculate geometry' function and are reported using the NAD 27 datum.

\section{SAMPLE PREPARATION}

Rock samples were prepared by ALS Minerals in accordance with their PREP-31 package, which involves crushing the entire sample to $<70 \%$ passing -10 mesh $(2 \mathrm{~mm})$, then splitting off 250 grams and pulverizing the split to $>85 \%$ passing 75 microns. Rock samples that were collected for slab XRF analysis were cut into 
nominal 4-cm-diameter disks using a tile saw. The surfaces to be analyzed were polished to a smooth, uniform surface using 60 grit and 220 grit compound on a lap wheel.

Stream-sediment samples were air dried in the bags by DGGS, and then submitted to ALS Minerals (formerly ALS Chemex), and underwent the PREP-41 package, where the sediments were logged, air-dried at low temperature, and weighed. The samples were then sieved to a particle size of -180 microns $(-80$ mesh). Both fractions were retained, and the -80 mesh fraction was crushed and used for analysis. Some samples lacking sufficient fine material were screened to -35 mesh prior to crushing.

Pan-concentrate samples were dried at DGGS using a hot plate and glass Petri dishes, which were washed after each use to prevent cross-contamination. Dried samples were weighed to the nearest 0.1 gram and then split manually into two equal-sized, homogeneous portions using a Sepor ${ }^{\mathrm{TM}}$ micro splitter, which was washed after each use. One split was retained by DGGS for mineralogical studies, the other split was submitted to ALS Minerals, and underwent the PREP-31 package, where the sample was logged, dried, weighed, and the entire sample was pulverized to a nominal 85 percent passing 75 microns (-180 mesh).

\section{ANALYTICAL METHODS}

All samples were analyzed for ore-related trace elements and the full suite of rare-earth elements. In addition to ALS Minerals' internal quality-control program accredited to ISO/IEC 17025-2005 standards, DGGS monitored analysis quality by inserting igneous-rock and ore-geochemical-pulp standards with known compositions into the sample roster for every sample batch.

a. Trace-element compositions were determined using inductively coupled plasma, atomic emission spectroscopy (ICP-AES) following a four-acid digestion process.

b. Rare-earth- and additional trace-element compositions were determined using inductively coupled plasma, mass spectroscopy (ICP-MS). ICP-MS samples were dissolved in acid following lithium metaborate fusion.

c. Whole-rock major oxides were obtained using X-Ray fluorescence spectroscopy using the ME-XRF06 method.

d. Platinum, palladium, and gold values were obtained from a 30-gram sample using inductively coupled plasma-atomic emission spectroscopy (ICP-AES) following fire assay.

e. Some samples were retested for quality control purposes and the results were not included in the publication because the variance of the samples had a mean of 1.25 percent and presented no significant change.

f. Samples over detection limits were resampled using specific elemental tests $\mathrm{Nb}, \mathrm{Sn}, \mathrm{U}$, Th, and W using the XRF-10 lithium borate fusion or for elements $\mathrm{Pb}$ and $\mathrm{Zn}$ using ME-OG62 four acid digestion.

Version 1.1 note: Additional XRF-10 lithium borate fusion analytical results were added for samples 12AT021A, 12AT022A, 12AT049, 12AT050, 12BW110, 12BW121, 12CW043, 12CW053, 12CW095, 12LF237A, 12LF238A, 12LF286, 12LF317A.

g. Slab XRF analysis-The XRF analyses were run on a PANalytical Axios spectrometer using SuperQ software. $\mathrm{Nb}, \mathrm{Rb}, \mathrm{Sr}, \mathrm{Y}$, and $\mathrm{Zr}$ were measured using SuperQ ${ }^{\mathrm{TM}} \mathrm{S} 37 \mathrm{mmRbSrYZr}$ routine software program; other elements were measured with the IQ+37mmVac software program. The $37 \mathrm{mmRbSrYZr}$ routine uses specifically predetermined peak and background positions for which X-ray intensities are measured for 2-800 seconds (depending on the element). The intensity of the Rh Compton peak is used to estimate mass-absorption coefficients (MACs) for both unknowns and well-characterized natural standards. Peak intensities are computed and converted to concentrations using calibration curves 
employing at least ten natural rock standards. These procedures are routinely checked by analysis of secondary natural standards that were not employed in making the calibration curves. Elemental abundances are typically within 2-5 percent of the amount present for concentrations $>10$ times the detection limit, within 5-10 percent of the amount present for concentrations 4-10 times the detection limit and within 30 percent of the amount present for concentrations near the detection limit. The IQ37mm Vac scans over a series of energies corresponding to a range from Ce-Kalpha to O-Kalpha. Peak heights and backgrounds and X-ray elemental interferences are picked with the software and checked manually to ensure quality control. Elemental abundances for all elements with atomic numbers between 8 and 92 are estimated from artificial standards and these estimations are used to calculate MACs for each element present above the detection limit. Revised concentrations are employed to calculate revised MACs until a stable solution is determined. Elemental abundances are then normalized to 100 percent. The software is routinely checked using pressed pellets of wellcharacterized natural rock standards. Elemental abundances are within 1-2 percent of the amount present for major elements, 2-5 percent of the amount present for minor elements, and 5-10 percent of the amount present for trace elements.

Detection limits for each of the reported elemental values obtained by the various methods are documented in the metadata file.

\section{REFERENCES}

Barker, J.C., 1992, Investigation of tin-rare-earth-element placers in the Ray River watershed: U.S. Bureau of Mines Open-File Report 34-91, 63 p., 1 sheet, scale 1:63,360. http://dggs.alaska.gov/pubs/id/21385

Barker, J.C., and Foley, J.Y., 1986, Tin reconnaissance of the Kanuti and Hodzana river uplands, central Alaska: U.S. Bureau of Mines IC9104, 27 p. http://dggs.alaska.gov/pubs/id/21287

Foley, J.Y., and McDermott, M.M., 1983, Podiform chromite occurrences in the Caribou Mountain and lower Kanuti River areas, central Alaska, Part I: Reconnaissance Investigations: U.S. Bureau of Mines IC 8915, 8 p., 1 sheet. http://dggs.alaska.gov/pubs/id/21279

Burns, L.E., Newberry, R.J., Bachmann, E.N., Blessington, M.J., Tuzzolino, A.L., and Werdon, M.B, 2012, Geologic resource assessment of strategic and critical minerals, Ray Mountains area, central Alaska [abs.]: Alaska Miners Association Annual Convention, Nov. 5-11, 2012, p. 16-18. http://www.alaska miners.org/abstracts2012.pdf

Smith, S.M., 2006, National geochemical database-Reformatted data from the National Uranium Resource Evaluation (NURE) Hydrogeochemical and Stream Sediment Reconnaissance (HSSR) Program: U.S. Geological Survey Open-File Report 97-492, version 1.40. http://dggs.alaska.gov/pubs/id/ $\underline{25462}$ 